\title{
PHYTOREMEDIATION OF SOIL CONTAMINATED WITH NICKEL BY LEPIDIUM SATIVUM; OPTIMIZATION BY RESPONSE SURFACE METHODOLOGY
}
A. MOJIRI ${ }^{1 *}$
H. ABDUL AZIZ
S. QARANI AZIZ ${ }^{2}$
M.R.B. SELAMAT ${ }^{1}$
A. GHOLAMI ${ }^{3}$
M. ABOUTORAB ${ }^{4}$

\author{
${ }^{1}$ School of Civil Engineering, Engineering Campus \\ University Sains Malaysia, 14300 Nibong Tebal \\ Penang, Malaysia \\ ${ }^{2}$ Department of Civil Engineering, College of Engineering \\ University of Salahaddin-Erbil, Iraq \\ ${ }^{3}$ Department of Soil Science, Science and Research Branch \\ Islamic Azad University, Khouzestan, Iran \\ ${ }^{4}$ Department of Food Science, Isfahan (Khorasgan) Branch \\ Islamic Azad University, Isfahan, Iran
}

Received: 25/09/12

Accepted: $30 / 10 / 12$

*to whom all correspondence should be addressed: e-mail: amin.mojiri@gmail.com

\section{ABSTRACT}

Phytoremediation is an alternative to traditional chemical and ways of treating polluted soils. The current study was carried out to investigate the phytoremediation of soil contaminated with nickel (Ni) by Lepidium sativum. Soil samples from 0 to $10 \mathrm{~cm}$ depth were collected. Lepidium sativum was transplanted in pots containing $5 \mathrm{~kg}$ of the collected soils. Central composite design and response surface methodology were employed in order to illustrate the nature of the response surface in the experimental design and explain the optimal conditions of the independent variables. Different concentrations for $\mathrm{Ni}\left(1\right.$ to $20 \mathrm{mg} \mathrm{kg}^{-1}$ ) and times for collecting samples (10 to 40 days) were used. The results showed the amount of Ni removed was ranged from $8.62 \mathrm{mg} \mathrm{kg}^{-1}$ (Ni concentration of 20 $\mathrm{mg} \mathrm{kg}^{-1}$ and time for taking samples of 10 days) to $7.066 \mathrm{mg} \mathrm{kg}^{-1}$ (Ni concentration of $10.50 \mathrm{mg} \mathrm{kg}^{-1}$ and time for taking samples of 40days). Additionally, the findings explained that the Lepidium sativum is an effective accumulator plant for phytoremediation of Ni polluted soils. Optimum conditions for nickel concentration and time for taking samples were $19.66 \mathrm{mg} \mathrm{kg}^{-1}$ and 39.28 days, respectively. For the optimum condition, the amount of Ni removed was $10.8095 \mathrm{mg} \mathrm{kg}^{-1}$.

KEYWORDS: Lepidium sativum, Nickel, Phytoremediation, RSM, Soil contaminated.

\section{INTRODUCTION}

Environmental contamination with heavy metals is a global disaster that is related to human activities such as mining, smelting, electroplating, energy and fuel production, power transmission, intensive agriculture, sludge dumping and melting operations. All the heavy metals with high concentrations have strong toxic effects and are regarded as environmental pollutants (Chehregani et al., 2009). Metals deposited to soil may transform (solubilise) into more mobile forms capable of migrating into the soil water where they may pose an elevated risk to plants, other soil biota and to groundwater (Ermakov et al., 2007). Restoration of soils polluted with potentially toxic metals and metalloids is of major global concern (Shelmerdine et al., 2009). Without doubt, environmental pollution is a major threat to our life. Industrialization, urbanization, and phenomenal growth in population are the factors for increasing pollution. In the last decade, much information has been obtained on the effect of heavy metal ions like nickel $(\mathrm{Ni})$ on the soil. $\mathrm{Ni}$ is a naturally occurring element that exists mostly in the form of sulphide ores found underground, and in silicate minerals, found on the surface. In the environment, $\mathrm{Ni}$ is found primarily combined with oxygen (oxides) or sulphur (sulfides) (Ministry of the Environment, 2001). Elevated levels of $\mathrm{Ni}\left(\mathrm{Ni}^{++}\right)$can pose a major threat to both human health and the environment (Hussain et al., 2010). 
The researches aims in recent years, obtain to methods to be appropriate environmental and costeffective for the cleanup of contaminated soils. Phytoremediation is a new and novel strategy to remove toxic heavy metals from soils through hyperaccumulator plant species. This is a low cost and eco-friendly means of reclaiming heavy metal contaminated soils, resulting from developmental activities, e.g. discharge of industrial effluents, city wastes, etc. (Panwar et al., 2002).

Phytoremediation basically refers to the use of plants and associated soil microbes to reduce the concentrations or toxic effects of contaminants in the environments (Greipsson, 2011). Phytoremediation is an alternative to traditional chemical and ways of treating polluted soils (Mathur et al., 2007). However, detoxification of organic pollutants by plants is slow, leading to the accumulation of toxic compounds that could be later released into the environment (Aken, 2008).

Phytoremediators have been studied for using in cleaning up heavy metals such as aluminium, cadmium, chromium, copper, mercury, Ni, lead and zinc (Ndimele, 2010). Plants that accumulate high concentrations of metals are sometimes referred to as "hyperaccumulators" (Visoottiviseth et al., 2002). Hyperaccumulator plants show a resource for remediation of metal contaminated sites, as they are able to extract wide range of metals and to concentrate them in their upper parts with the character of metal tolerance (Sarma, 2011). In literature, many plants were used for phytoremediation of heavy metals from soil (Mojiri, 2011; Cruz-Landero et al., 2010; Jadia and Fulekar, 2009; Chehregani et al., 2009; Zhang et al., 2009; Xiao et al., 2008; Subroto et al., 2007; AlFarraj and Al-Wabel, 2007; Ok and Kim, 2007; Cho-Ruk et al., 2006; Lombi et al., 2001).

Lepidium sativum commonly called "Garden Cress" is a polymorphic species (Karazhiyan et al., 2009). It is a native plant of South West Asia, which spread many centuries ago to western European. It was used by ancient Egyptians as a food source and became well known in various parts of Europe, including Britain, France, Italy and Germany in due course, where it is still used as a minor crop. Persian used to eat this plant even before bread was known (Sharma and Agarwal, 2011). In literature, Lepidium sativum is a plant that is used for phytoremediation of soil heavy metals contaminated (Gunduz et al., 2012; Kiayee et al., 2012; Kathi and Khan, 2011).

The goals of this study were: 1) the phytoremediation of soil contaminated with $\mathrm{Ni}$ by Lepidium sativum and 2) Optimization by response surface methodology (RSM).

\section{MATERIALS AND METHODS}

\subsection{Site description, Sample preparation}

The experiment was carried out at the greenhouse. Soil samplings from 0 to $10 \mathrm{~cm}$ depth were collected in 2011. Lepidium sativum was transplanted in pots containing $5 \mathrm{~kg}$ of the collected soils. Central composite design (CCD) and response surface methodology (RSM) were employed to illustrate the nature of the response surface in the experimental design and to show the optimal conditions of the variables. Different Ni concentrations ( 1 to $20 \mathrm{mg} \mathrm{kg}^{-1}$ ) and times for taking samples (10 to 40 days) were applied.

\subsection{Laboratory determinations}

Soil texture was determined by the Bouyoucos hydrometer method (Gee and Bauder, 1986). Soil pH and electrical conductivity (EC) were measured on 1:1 extract (Soil:Water). Total Ni in soil samples was carried out in accordance the Standard Methods (APHA, 2005). Soil organic matter (OM) was determined as in Walkley and Black and cation exchange capacity (CEC) was determined (ASA, 1982).

Soil samples were allowed to air dry in a greenhouse at a temperature between $25^{\circ} \mathrm{C}$ and $30^{\circ} \mathrm{C}$ and were then ground to pass a 2-mm mesh sieve for prepared of soil samples (Makoi and Verplancke, 2010; Mojiri and Amirossadat, 2011). The plant tissues were prepared by Wet Digestion Method (Campbell and Plank, 1998).

\subsection{Experimental design and data analysis}

CCD and RSM were employed in order to illustrate the nature of the response surface in the experimental design and elucidate the optimal conditions of the independent variables. CCD was established through Design Expert Software (6.0.7). The behavior of the system is described through Eq. (1) an empirical second-order polynomial model: 


$$
Y=\beta \sum_{i=1}^{k} \beta i X i+\sum_{i=1}^{k} \beta i X i 2+\sum_{i<j}^{k} \quad \sum_{j}^{k} \beta i j X i X j+\cdots+e
$$

where $Y$ is the response; $X i$ and $X j$ are the variables; $\beta 0$ is a constant coefficient; $\beta \mathrm{j}, \beta \mathrm{jj}$, and $\beta \mathrm{ij}$ are the interaction coefficients of linear, quadratic and second-order terms, respectively; $k$ is the number of studied factors; and $\mathrm{e}$ is the error.

The results were completely analyzed by analysis of variance (ANOVA) in the Design Expert Software. Nickel concentrations $\left(1,10.50\right.$, and $\left.20 \mathrm{mg} \mathrm{kg}^{-1}\right)$ and times for taking samples $(10,25$, and 40 days) were used. To carry out an adequate analysis, one dependent parameter (reducing nickel concentration in soil) was measured as responses (Table 2).

Descriptive statistical analysis including mean comparison of $\mathrm{Ni}$ accumulation in roots and shoots of plant using Duncan's Multiple Range Test (DMRT) was conducted using SPSS software.

\section{RESULTS AND DISCUSSIONS}

Soil properties before experiment, results of the experiments, ANOVA results for response parameter, comparing the means of $\mathrm{Ni}$ accumulation in Lepidium sativum roots, and shoots are shown in Tables 1, 2, 3 and 4, respectively. Design expert plot; response surface plot for Ni removal and design-expert plot; predicted vs. actual values plot for nickel removal are shown in Figures 1 and 2 , respectively.

In this work, RSM was used for analyzing the correlation between the variables ( $\mathrm{Ni}$ concentrations and times for taking samples) and the important process response (the amount of $\mathrm{Ni}$ removed). Considerable model terms were preferred to achieve the best fit in a particular model. CCD permitted the development of mathematical equations where predicted results $(Y)$ were evaluated as a function of $\mathrm{Ni}$ concentration $(\mathrm{A})$ and times for taking samples (B). The results were computed as the sum of a constant, two first order effects (terms in $A$ and $B$ ), one interaction effect (AB), and two second-order effects $\left(A^{2}\right.$ and $\left.B^{2}\right)$, as shown in the equation (Table 3 ). The results were analyzed by ANOVA to determine the accuracy of fit. Table 3 shows the quadratic models in terms of actual factors, it means that the arrangement of variables such as $A, B, A^{2}, B^{2}$ and $A^{*} B$ are exist in the equation. The model was significant at the $5 \%$ confidence level because probability values were less than 0.05 . The lack of fit (LOF) F-test explains variation of the data around the modified model. LOF was significant, if the model did not fit the data well. Generally, large probability values for LOF $(>0.05)$ explained that the F-statistic was insignificant, implying significant model relationship between variables and process responses. The $\mathrm{R}^{2}$ gave the proportion of total variation in the response predicted by the model, indicating the ratio of sum of squares due to regression to total sum of squares. $R^{2}$ value close to 1 was desirable, and a high $R^{2}$ coefficient ensured acceptable modification of the quadratic model to the experimental data. Adequate precision compared the range of the predicted values at the design points to the mean prediction error. The suitability of the model could be judged by diagnostic plots i.e. predicted vs. actual values. Figure 2 shows the predicted vs. actual value plots of the response parameters. This plot signified a sufficient agreement between the real data and the values achieved from the model. The coefficient of variance $(\mathrm{CV})$ is the ratio of the standard error of estimate to the average value of the observed response defined by the reproducibility of the model.

Table 1. Soil properties before experiment

\begin{tabular}{cccccccc}
\hline Ph & $\begin{array}{c}\mathrm{EC} \\
\left(\mathbf{d S m}^{-1}\right)\end{array}$ & $\begin{array}{c}\text { CEC } \\
\left(\mathrm{me} \mathrm{100g}^{-1}\right)\end{array}$ & $\begin{array}{c}\text { OM } \\
(\%)\end{array}$ & $\begin{array}{c}\text { Clay } \\
(\%)\end{array}$ & $\begin{array}{c}\text { Sand } \\
(\%)\end{array}$ & $\begin{array}{c}\text { Silt } \\
(\%)\end{array}$ & $\begin{array}{c}\mathbf{N i} \\
(\mathbf{p p m})\end{array}$ \\
\hline \multicolumn{7}{c}{ Main Soil (T1) } \\
6.97 & 1.14 & 9.6 & 0.70 & 10.00 & 60.90 & 29.10 & 0.0 \\
\hline
\end{tabular}


Table 2. Experimental variables and results for the removal nickel concentration in soil

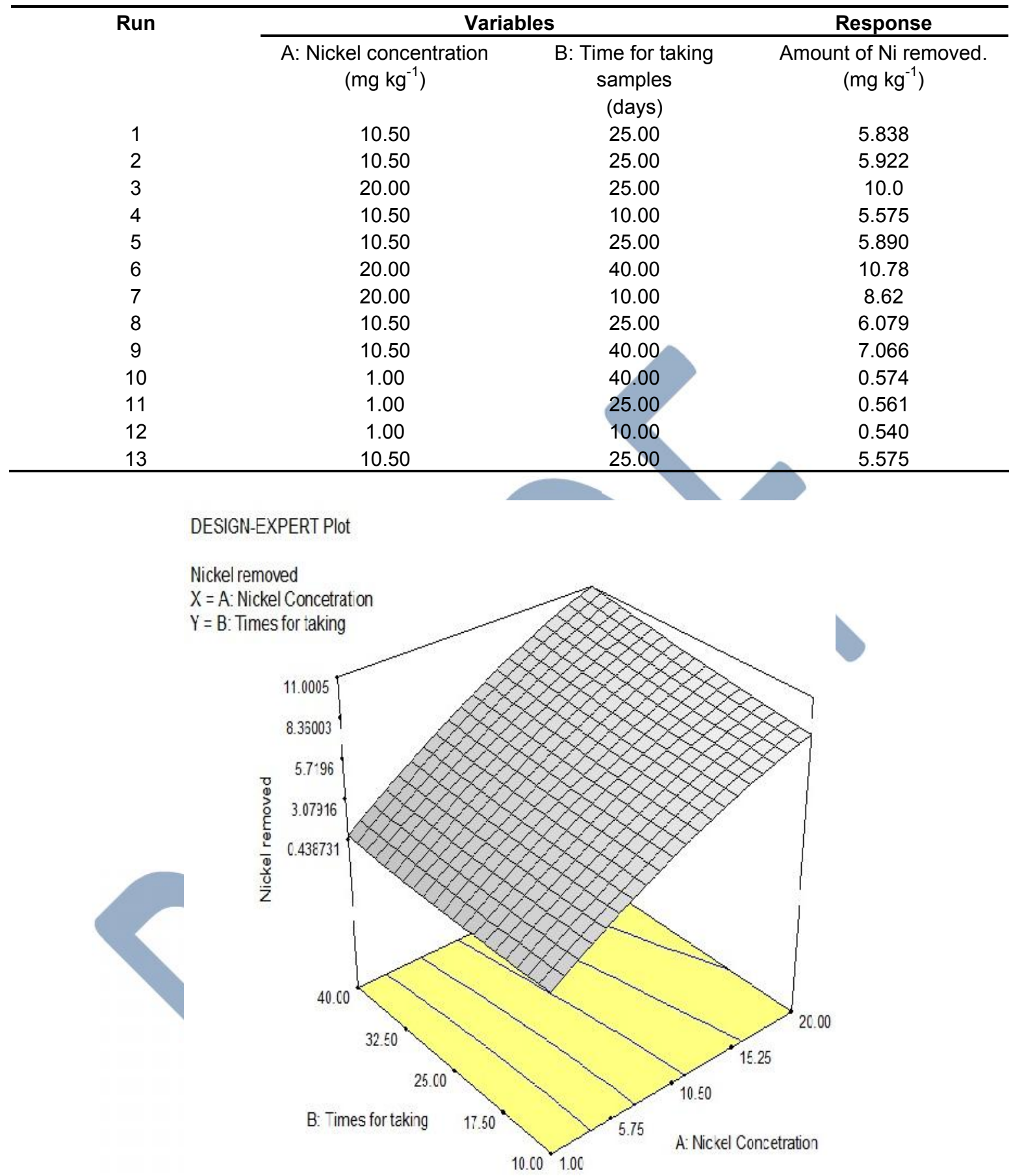

Figure 1. Design expert plot; response surface plot for nickel removal

Table 3. ANOVA results for response parameter

\begin{tabular}{ccccccccc}
\hline Response & Prob. & $\mathbf{R}^{2}$ & Adj. $\mathbf{R}^{2}$ & $\begin{array}{c}\text { Adec. } \\
\text { P. }\end{array}$ & SD & CV & PRESS & $\begin{array}{c}\text { Prob. } \\
\text { LOF }\end{array}$ \\
\hline $\begin{array}{c}\text { Nickel } \\
\text { Removal }\end{array}$ & 0.0001 & 0.9965 & 0.9945 & 59.724 & 0.26 & 4.63 & 2.78 & 0.136 \\
\hline
\end{tabular}

Final equation in terms of actual factor $=0.18042+0.59690 \mathrm{~A}-0.034751 \mathrm{~B}-0.003 \mathrm{~A}^{2}-0.004 \mathrm{~B}^{2}-0.003 \mathrm{AB}$ where $\mathrm{A}$ is $\mathrm{Ni}$ concentration) and $\mathrm{B}$ is time for taking samples 


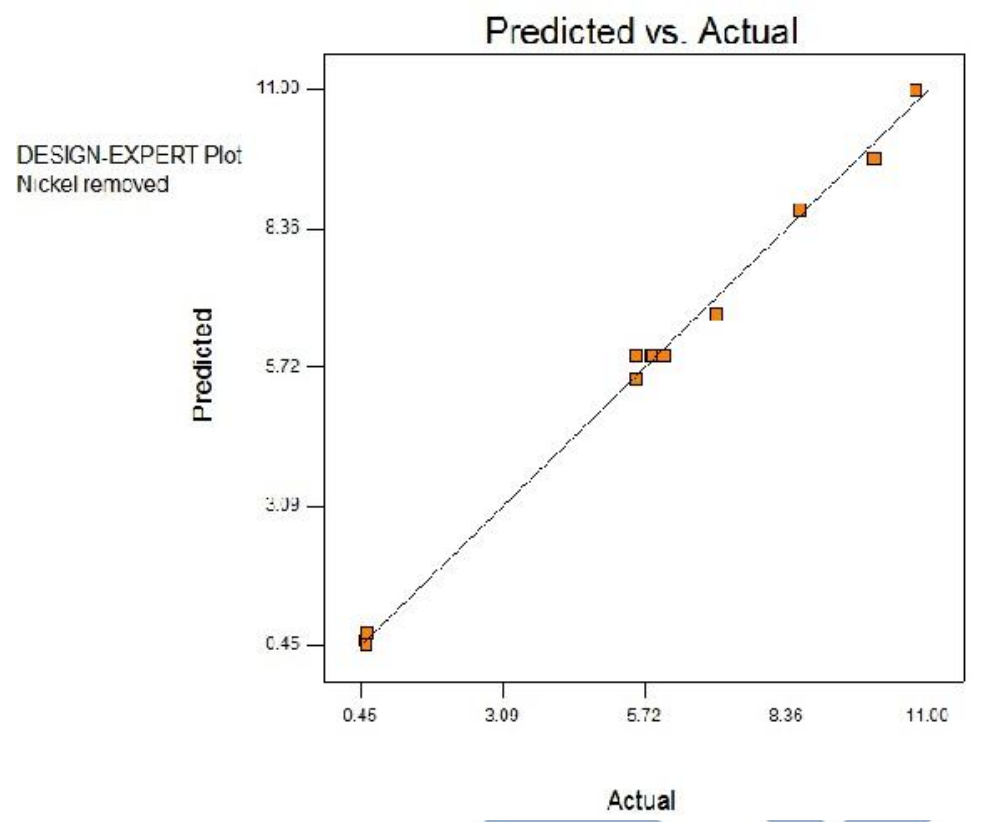

Figure 2. Design-expert plot; predicted vs, actual values plot for níckel removal

The amount of Ni removed ranged from $8.62 \mathrm{mg} \mathrm{kg}^{-1}$ (Ni concentration of $20 \mathrm{mg} \mathrm{kg}^{-1}$ and time for taking samples of 10 days) to $7.066 \mathrm{mg} \mathrm{kg}^{-1}$ (Ni concentration of $10.50 \mathrm{mg} \mathrm{kg}^{-1}$ and time for taking samples of 40 days). The phytoremediation of $\mathrm{Ni}$ increases, when the $\mathrm{Ni}$ concentration was increased till 10.50 and after that pheytoremedion of $\mathrm{Ni}$ was decreased. It can be noticed from Figure 1 that the increase in the times for taking samples was resulted in amount of removed $\mathrm{Ni}$.

Optimum conditions for nickel concentration and time for taking samples were $19.66 \mathrm{mg} \mathrm{kg}^{-1}$ and 39.28 days, respectively. For the optimum condition, the amount of Ni removed was $10.8095 \mathrm{mg} \mathrm{kg}^{-1}$.

Table 4. Comparing the means of treatments in Lepidium sativum

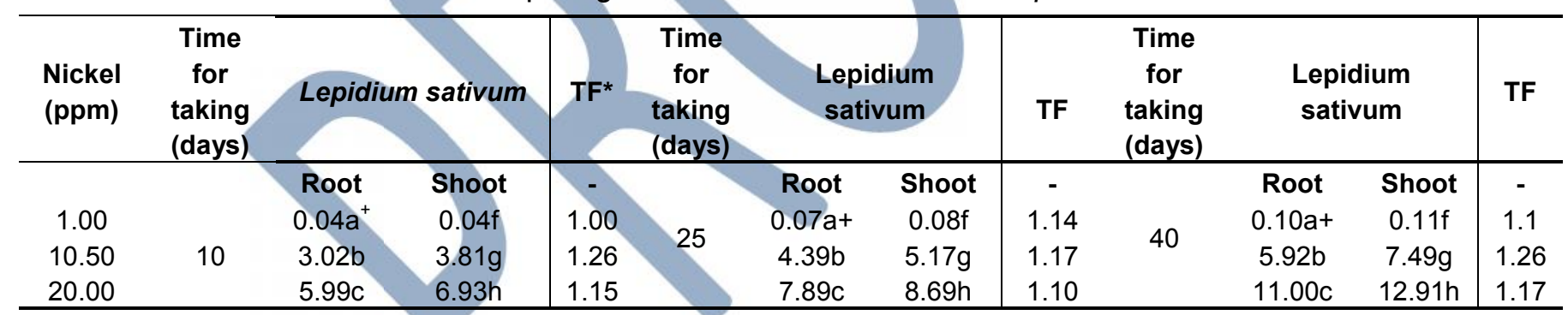

+ Row means followed by the same letter are not significantly different at 0.05 probability level

${ }^{*}$ TF: translocation factor

The efficiency of phytoremediation can be quantified by calculating translocation factor. The translocation factor indicates the efficiency of the plant in translocating the accumulated metal from its roots to shoots. It is calculated as follows (Padmavathiamma and Li, 2007).

Translocation Factor (TF) $=\frac{C \text { shoot }}{C \text { root }}$

where $\mathrm{C}_{\text {shoot }}$ is concentration of the metal in plant shoots and $\mathrm{C}_{\text {root }}$ is concentration of the metal in plant roots.

Based on Table 4, translocation factors (TF) were more than 1 in all treatments. Translocation factor value greater than 1 indicates the translocation of the metal from root to above-ground part (Jamil et al., 2009). According to Yoon et al. (2006), only plant species with TF greater than 1 have the potential to be used for phytoextraction.

Accumulation of $\mathrm{Ni}$ in roots was 0.40 ( $\mathrm{Ni}$ concentration of 1 and time for taking samples of 10 ) to 11.00 ( $\mathrm{Ni}$ concentration of 1 and time for taking samples of 40 days). Heavy metals when present at 
an elevated level in soil are absorbed by the root system, accumulate in different parts of plants, reduce their growth and impair metabolism (Kiyaee et al., 2012).

\section{CONCLUSIONS}

Environmental pollution with heavy metals is a global disaster that is related to human activities. Phytoremediation is a new and novel strategy to remove toxic heavy metals from soils through hyperaccumulator plant species. At the optimum conditions of $N i$ concentration $\left(19.66 \mathrm{mg} \mathrm{kg}^{-1}\right)$ and time for taking samples (39.28 days), the amount of Ni removed was $10.8095 \mathrm{mg} \mathrm{kg}^{-1}$. The evidence provided by this experiment indicated that Lepidium sativum is an effective accumulator plant for phytoremediation of Ni polluted soils because the translocation factor was greater than 1 .

\section{ACKNOWLEDGMENTS}

The authors would like to acknowledge the University Sains Malaysia (USM) for their support.

\section{REFERENCES}

Aken B.V. (2008), Transgenic plants for phytoremediation: helping nature to clean up environmental pollution, Trends in Biotechnology, 26, 225-227.

Al-Farraj A.S. and Al-Wabel M.I. (2007), Heavy Metals Accumulation of Some Plant Species Grown on Mining Area at Mahad AD 'Dahab, Saudi Arabia, Journal of Applied Sciences, 7, 1170-1175.

APHA. (2005), Standard Methods for Examination of Water and Wastewater, 20th ed. American Public Health Association, Washington, DC, USA.

ASA (1982), Methods of Soil Analysis. Part 2. Chemical and Microbiological Properties, 2nd edition, Page A.L. (Ed.), Agronomy Society of America.

Campbell C.R. and Plank C.O. (1998), Preparation of plant tissue for laboratory analysis. P 37-49. In Y.P. Kalra (ed) Handbook of Reference Method for Plant Analysis. CRC Press, Boca Raton, FL.

Chehregani A., Noori M. and Yazdi L.H. (2009), Phytoremediation of heavy-metal-polluted soils: Screening for new accumulator plants in Angouran mine (Iran) and evaluation of removal ability, Ecotoxicology and Environmental Safety, 72, 1349-1353.

Cho-Ruk K., Kurukote J., Supprung P. and Vetayasuporn S. (2006), Perennial Plants in the Phytoremediation of Lead-contaminated Soils, Biotechnology, 5, 1-4.

Cruz-Landero N.D.L., Hernandez V.E., Guevara E., Lopez-Lopez M.A., Santos A.T., Ojeda-Trejo E. and Alderete-Chavez A. (2010), Lupinus versicolor Response in Soils Contaminated with Heavy Metals from a Petroleum Extraction Field, Journal of Applied Sciences, 10, 694-698.

Ermakov I.V., Koptsik S.V., Koptsik G.N. and Lofts S. (2007), Transport and Accumulation of Heavy Metals in Undisturbed Soil Columns, Global NEST Journal, 9(3), 187-194.

Gee G.W. and Bauder J.W. (1986), Particle-size analysis. In: Klute, A. (Ed.), Methods of Soil Analysis, Part 1. Physical and Mineralogical Methods, 2end ed., Agronomy, 9, 383-411.

Greipsson S. (2011), Phytoremediation. Nature Education Knowledge 2, 7.

Gunduz S., Uygur F.N. and Kahramanoğlu I. (2012), Heavy metal Phytoremediation potentials of Lepidum sativum L., Lactuca sativa L., Spinacia oleracea L. and Raphanus sativus L, Agriculture and Food Science Research, 1(1), 001-005.

Hussain S.T., Mahmood T. and Malik S.A. (2010), Phytoremediation technologies for $\mathrm{Ni}^{++}$by water hyacinth, African Journal of Biotechnology, 9(50), 8648-8660.

Jadia C.D. and Fulekar M.H. (2009), Phytoremediation of heavy metals: Recent techniques. African Journal of Biotechnology, 8(6), 921-928.

Jamil S., Abhilash P.C., Singh N. and Sharma P.N. 2009. Jatropha curcas: A potential crop for phytoremediation of coal fly ash., J. Hazard. Mater., 172, 269-275.

Karazhiyan H., Razavi S.M.A., Phillips G.O., Fang Y., Al-Assaf S., Nishinari K. and Farhoosh R. (2009), Rheological properties of Lepidium sativum seed extract as a function of concentration, temperature and time, Food Hydrocolloids, 23, 2062-2068.

Kathi S. and Khan A.B. (2011), Phytoremediation approaches to PAH contaminated soil, Indian Journal of Science and Technology, 4(1), 56-63.

Kiayee S.B., Kumleh A.S. and Amirossadat, Z. (2012), Phytoextraction of Lead from Soil by Lepidium sativum L., Caspian Journal of Applied Sciences Research, 1(1), 1-6. 
Lombi, E., Zhao F.J., Dunham S.J. and McGrath S.P. (2001), Phytoremediation of heavy metalcontaminated soils: natural hyperaccumulation versus chemically enhanced phytoextraction. $J$. Environ. Qual., 30(6), 1919-1926.

Makoi J. and Verplancke H. (2010), Effect of gypsum placement on the physical chemical properties of a saline sandy loam soil, Australian Journal of Crop Science, 4(7), 556-563.

Ministry of the Environment. (2001), Nickel in the environment. Ontario, fact sheet, March 2001.

Mojiri A. (2011), The Potential of Corn (Zea mays) for Phytoremediation of Soil Contaminated with Cadmium and Lead, J. BIOL. ENVIRON. SCI., 5(13), 17-22.

Mojiri A. and Amirossadat Z. (2011). Effects of Urban Wastewater on Accumulation of Heavy Metals in Soil and Corn (Zea mays L) with Sprinkler Irrigation Method, Asian Journal of Plant Sciences, 10(3), 233- 237.

Mathur N, Bohra J.S.S., Quaizi A. and Vyas A. (2007), Arbuscular Mycorrhizal Fungi: A Potential Tool for Phytoremediation, Journal of Plant Sciences, 2, 127-140.

Ndimele P.E. (2010), A Review on the Phytoremediation of Petroleum Hydrocarbon., Pakistan Journal of Biological Sciences, 13: 715-722.

Ok Y.S. and Kim J.G. (2007), Enhancement of Cadmium Phytoextraction from Contaminated Soils with Artemisia princeps var.orientalis, Journal of Applied Sciences, 7, 263-268.

Panwar B.S., Ahmed K.S. and Mittal S.B. (2002), Phytoremediation of Nickel-Contaminated Soils by Brassica Species. ENVIRONMENT, DEVELOPMENT AND SUSTAINABILITY, 4(1), 1-6.

Padmavathiamma P.K. and Li L.Y. (2007), Phytoremediation technology: hyper accumulation metals in plants, Water Air Soil Pollut., 184: 105-126.

Sarma H. (2011), Metal Hyperaccumulation in Plants: A Review Focusing on Phytoremediation Technology, Journal of Environmental Science and Technology, 4, 118-138.

Sharma S. and Agarwal N. (2011), Nourishing and healing prowess of garden cress (Lepidium sativum Linn.) A review, Indian Journal of Natural Products and Resources, 2(3), 292-297.

Shelmerdine A., Black C., McGrath S. and Young S. (2009), Modelling phytoremediation by the hyperaccumulating fern, Pteris vittata, of soils historically contaminated with arsenic, Environmental Pollution, 157, 1589-1596.

Subroto M.A., Priambodo S. and Indrasti N.S. (2007), Accumulation of Zinc by Hairy Root Cultures ofSolanum nigrum, Biotechnology, 6, 344-348.

Visoottiviseth P., Francesconi K. and Sridokchan W. (2002), The potential of Thai indigenous plant species for the phytoremediation of arsenic contaminated land, Environmental Pollution, 118, 453461.

Xiao X., Tongbin C., Zhizhuang A. and Mei L. (2008), Potential of Pteris vittata L. for phytoremediation of sites co-contaminated with cadmium and arsenic: The tolerance and accumulation, Journal of Environmental Sciences, 20, 62-67.

Yoon J., Cao X., Zhou Q. and Ma L.Q. (2006), Accumulation of $\mathrm{Pb}, \mathrm{Cu}$, and $\mathrm{Zn}$ in native plants growing on a contaminated Florida site, Sci. Total Environ., 368, 456-464.

Zhang H., Dang Z., YI X.Y., Yang C., Zheng L.C. and Lu C.N. (2009), Evaluation of Dissipation Mechanism for Pyrene by Maize (Zea Mays L.) in Cadmium Co-Contaminated Soil, Global NEST Journal, 11(4), 487-496 